\title{
Pengaruh Ukuran Perusahaan, Umur Perusahaan, Profitabilitas, Solvabilitas dan Likuiditas Terhadap Audit Report Lag
}

\author{
Sofi Dwiastuti Agustina ${ }^{1}$ Jaeni $^{2}$ \\ Universitas Stikubank Semarang \\ sofidwiastuti23@gmail.com, jaenimunawar131@gmail.com
}

*Penulis Korespondensi

Diajukan : 15 Desember 2021

Disetujui : : 1 Januari 2022

Dipublikasi : 7 Januari 2022

\begin{abstract}
The puncuality of audited financial report delivery is one measure for company owners, the community, especially investors for decision making. Therefore, this study seeks to examine the effect of company size, company age, profitability, solvency, and liquidity on audit report lag on tourism companies listed on the Indonesia Stock Exchange for the 2016-2020 period. This study uses secondary data in the from of financial statement and independent auditor report. The number of samples in this study were 16 companies, selected with certain criteria using purposive sampling technique. The data analysis technique used in this research is panel data regression analysis using Eviews 9 software, in addition, the previous classical assumtion test also included multicolinearity test, heterocedasticity test, and autocoleration test. The study found that (1) Company size does not influence audit report lag, (2) Company age has a positive effect on audit report lag, (3) Profitability has a negative effect on audit report lag, (4) Solvability does not influence audit report lag, and (5) Liquidity does not influence audit report lag. For the researchers, it is recommended to increase the sample size and expand the object of research by researching sectors that have more companies and also increasing the period of research.
\end{abstract}

Keywords:audit report lag; company size; company age; profitability; solvability

\section{PENDAHULUAN}

Perkembangan kemajuan teknologi yang semakin canggih menandakan adanya era globalisasi membuat persaingan bisnis semakin ketat dan kompetitif. Maka dari itu, setiap perusahaan harus dituntut memiliki kepekaan agar terus dapat berkembang dengan strategi perusahaan untuk tetap bertahan di dalam persaingan yang ada, sehingga dapat meningkatlkan kinerja perusahaan. Lingkungan global sangat berpengaruh dalam dunia bisnis sehingga manajemen suatu perusahaan sebaiknya memiliki strategi baru untuk perusahaan agar dapat bertahan, termasuk perusahaan pariwisata. Setiap perusahaan manufaktur yang terdaftar di Bursa Efek Indonesia wajib menyampaikan laporan keuangan yang telah diaudit ke pihak eksternal.

Laporan keuangan adalah catatan informasi keuangan dari suatu perusahaan pada satu periode akuntansi. Laporan keuangan memiliki peran penting yang dapat digunakan untuk menggambarkan kinerja suatu perusahaan tersebut. Menurut Ikatan Akuntansi Indonesia (2009:3), tujuan dari laporan keuangan adalah menyediakan informasi yang menyangkut posisi keuangan, kinerja, serta perubahan posisi keuangan, kinerja, serta perubahan posisi keuangan suatu perusahaan yang bermanfaat bagi sejumlah besar pemakai dalam pengambilan keputusan. Laporan keuangan akan bermanfaat apabila laporan keuangan yang disajikan secara andal, relevan, dapat diperbandingkan, dan mudah dipahami (PSAK: 2009).

Menurut peraturan yang ditetapkan oleh Badan Pengawas Pasar Modal dan Lembaga Keuangan (BAPEPAM-LK) Nomor Kep/346/BL/2011 tentang kewajiban penyampaian laporan keuangan tahunan menyatakan bahwa bagi emiten atau perusahaan go public yang pernyataan pendaftarannya telah menjadi efektif wajib menyampaikan laporan keuangan beserta dengan 
laporan auditor independen kepada Bapepam dan LK selambat - lambatnya 3 bulan (90 hari) setelah tahun buku berakhir. Ketepatan waktu (timeliness) dalam penyajian laporan keuangan tergantung pada waktu auditor dalam melakukan proses pengauditan laporan keuangan. Dalam proses pengauditan, auditor harus melakukan auditnya dengan perencanaan yang matang dan mengumpulkan bukti yang cukup memadai. Oleh karena itu, hal ini dapat menyebabkan lamanya suatu proses pengauditan dilakukan hingga publikasi yang diharapkan tepat waktu menjadi terlambat waktunya. Relevansi laporan keuangan adalah yang disajikan secara tepat waktu, jadi semakin cepat informasi laporan keuangan di publikasikan maka akan semakin bermanfaat dalam pengamilan keputusan, dan sebaliknya jika terlambat mempublikasikan laporan keuangan, maka laporan keuangan tersebut akan kehilangan relevansinya. Waktu yang digunakan oleh auditor dalam menyelesaikan pengauditan laporan keuangan diukur berdasarkan lamanya hari sejak tanggal tahun tutup buku per akhir tahun (31 Desember) sampai tanggal yang tertera pada laporan auditor independen, perbedaan waktu tersebut disebut audit report lag. Semakin lama auditor dalam menyelesaikan pengauditan laporan keuangan, maka akan semakin panjang audit report lag. Audit report lag yang lama akan memberikan dampak negatif bagi perusahaan khususnya para pemegang saham tentu akan menjadi berita buruk (bad news).

Fenomena audit report lag di Indonesia bukanlah suatu hal yang baru, terlepas dari adanya penetapan peraturan terkait penyampaian laporan keuangan, keterlambatan dalam penyampaian laporan keuangan yang telah di audit masih kerap terjadi di beberapa perusahaan. Pada masa pandemi Covid-19 memberikan dampak yang besar terhadap hampir semua sektor industri, terutama pada sektor pariwisata. Kebijakan pandemi atau pembatasan aktivitas yang dikeluarkan oleh pemerintah semakin menghambat laju perputaran roda bisnis. Masyarakat terus dibatasi dalam hal, salah satunya menciptakan sistem bekerja dari rumah atau yang disebut juga sebagai sistem kerja Work Form Home (WFH). Berikut di bawah ini terdapat tabel audit report lag sebelum dan selama masa pandemi Covid-19

Tabel 1. Perusahaan yang Terlambat Menyampaikan Laporan Keuangan

\begin{tabular}{|c|c|c|c|}
\hline & Tahun & $\begin{array}{c}\text { Perusahaan yang } \\
\text { Terlambat }\end{array}$ & Presentase \\
\hline \multirow{3}{*}{ Sebelum Pandemi } & 2016 & 31 & - \\
\cline { 2 - 4 } & 2017 & 10 & $-9,69 \%$ \\
\cline { 2 - 4 } & 2018 & 10 & $0 \%$ \\
\hline Selama Pandemi & 2019 & 26 & $+26 \%$ \\
\hline
\end{tabular}

Sumber: data sekunder yang di olah (2021)

Dalam tabel 1 memperlihatkan bahwa pada masa pandemi Covid-19 yakni pada tahun 2020 perusahaan yang terlambat menyampaikan laporan keuangan sebanyak 56 perusahaan (naik 26,48 persen). Hal ini berarti bahwa penerapan sistem kerja work form home ternyata meiliki tantangan dan kendala yang tidak mudah, tidak semua pekerjaan dapat dikerjakan dari rumah, sehingga dapat menyebabkan auditor memerlukan waktu yang lama dalam penyelesaian laporan keuangan karena auditor dengan membutuhkan informasi yang akurat serta ketepatan waktu yang diminta.

Waktu yang digunakan oleh auditor dalam menyelesaikan pengauditan laporan keuangan diukur berdasarkan lamanya hari sejak tanggal tahun tutup buku per akhir tahun (31 Desember) sampai tanggal yang tertera pada laporan auditor independen, perbedaan waktu tersebut disebut audit report lag. Semakin lama auditor dalam menyelesaikan pengauditan laporan keuangan, maka akan semakin panjang audit report lag. Audit report lag sangat berkaitan erat dengan agency theory, dalam hubungan keagenan terdapat suatu kontrak dimana perusahaan bertindak sebagai principal memerintah auditor yang bertindak sebagai agent. Perusahaan harus memberikan apa saja yang dibutuhkan oleh auditor dan auditor juga harus dapat menyelesaikan kewajibannya dengan baik dan memberikan hasil yang memuaskan kepada perusahaan sehingga kepentingan masingmasing akan terpenuhi (Jensen \& Meckling, 1976).

Hubungan antara ukuran perusahaan dengan audit report lag adalah sebuah perusahaan besar akan menyelesaikan proses auditnya lebih cepat dibandingkan dengan perusahaan yang lebih kecil 
atau menengah (Dura, 2017). Perusahaan dengan umur yang lama juga memiliki pengendalian internal yang baik, dan juga mampu dalam mengumpulkan informasi yang dibutuhkan seorang auditor dalam melakukan pekerjaan auditnya. Menurut Dura (2017) semakin tinggi profitabilitas yang dimiliki perusahaan maka akan mempercepat penyampaian lapora keuangan begitu pula sebaliknya. Jika sebuah perusahaan mampu membayar hutang-hutangnya bisa dikatakan bahwa perusahaan tersebut akan mampu menyajikan laporan keuangannya dengan tepat waktu (Pebi, 2013) dalam Artaningrum, et.al., (2017). Tingginya tingkat likuiditas perusahaan menggambarkan bahwa perusahaan memiliki kinerja yang baik sehingga pihak manajemen diduga cenderung lebih cepat dalam menyampaikan laporan keuangan perusahaan.

Tujuan penelitian ini adalah menguji pengaruh ukuran perusahaan, umur perusahaan, profitabilitas, solvabilitas da likuiditas terhadap audit report lag. Perbedaan penelitian ini dengan penelitian terdahulu terletak pada sampel dan periode penelitian. Penelitian ini dilakukan pada perusahaan pariwisata yang terdaftar di Bursa Efek Indonesia pada periode 2016 sampai 2020. Sesuai dengan pembahasan di atas, pengembagan ini dilakukan untuk mengetahui secara jelas dan melihat hubungan yang lebih spesifik mengenai pengaruh variabel ukuran perusahaan, umur perusahaan, profitabilitas, solvabilitas dan likuiditas yang mempengaruhi Audit Report Lag.

\section{Penelitian Terdahulu}

\section{STUDI LITERATUR}

Audit Report Lag adalah rentang waktu antara tanggal penyajian laporan keuangan dengan tanggal terbitnya laporan audit (Halim, 2000). Atau dapat dikatakan rentang waktu tersebut adalah lamanya waktu auditor melakukan pekerjaan auditnya. Lamanya waktu penyelesaian audit dapat mempengaruhi ketepatan waktu (timelines) informasi untuk dipublikasikan sehingga berdampak pada reaksi pasar terhadap keterlambatan informasi dan mempengaruhi tingkat ketidakpastian keputusan yang didasarkan pada informasi yang dipublikasikan. Untuk melihat ketepatan waktu biasanya suatu penelitian melihat keterlambatan (lag). Tujuan audit suatu laporan keuangan adalah menyatakan pendapat mengenai kewajaran laporan keuangan perusahaan. Apakah laporan keuangan perusahaan tersebut menyajikan secara wajar dalam semua hal material sesuai dengan prinsip akuntansi yang berlaku umum. Ketepatan waktu dalam penyampaian laporan keuangan auditan merupakan hal yang sangat penting bagi perusahaan publik. Menurut Knechel dan Payne (2001) audit report lag dibagi menjadi tiga komponen yaitu:

1. Scheduling lag, yaitu selisih waktu antara akhir tahun fiskal perusahaan dengan dimulainya pekerjaan lapangan auditor.

2. Fieldwork lag, yaitu selisih waktu antara dimulainya pekerjaan lapangan auditor dengan saat penyelesaian audit.

3. Reporting lag, yaitu selisih waktu antara saat penyelesaian pekerjaan lapangan auditor sebelum tanggal laporan audit.

\section{Ukuran Perusahaan terhadap Audit Report Lag}

Menurut Aristika, et.al., (2016) Ukuran perusahaan menunjukkan besar kecilnya sebuah perusahaan yang dilihat dari beberapa sudut pandang seperti total nilai aset, total penjualan, jumlah tenaga kerja, anak perusahaan dan sebagainya. Menurut penelitian yang dilakukan Sunarsih, et.al., (2021) menunjukkan bahwa ukuran perusahaan berpengaruh positif terhadap audit report lag. Besar atau kecilnya jumlah aset yang dimiliki oleh perusahaan dapat mempengaruhi panjang atau pendeknya proses penyusunan laporan keuangan pada perusahaan tersebut. Penelitian yang dilakukan oleh Pertiwi (2021) mengungkapkan hasil bahwa ukuran perusahaan berpengaruh signifikan terhadap audit report lag. Sedangkan penelitian yang dilakukan oleh Natalia, et.al., (2021) menunjukkan bahwa ukuran perusahaan tidak berpengaruh terhadap audit report lag.

$\mathrm{H}_{1}$ : Ukuran perusahaan berpengaruh signifikan terhadap audit report lag

\section{Umur Perusahaan terhadap Audit Report Lag}

Umur perusahaan merupakan umur perusahaan atau lamanya perusahaan sejak terdaftar di BEI. Umur perusahaan dihitung dari tahun perusahaan listing di BEI sampai dengan tahun penelitian. Menurut Widiastuti \& Kartika (2018) semakin lamanya umur listing perusahaan maka 
jangka waktu pelaporan auditnya akan semakin cepat, demikian jika umur listing perusahaan tersebut masih baru maka jangka waktu pelaporan auditnya akan semakin lama. Perusahaan yang telah lama berdiri umumnya telah melakukan ekspansi dengan membuka cabang atau usaha di beberapa daerah. Menurut Widhiasari \& Budhiarta (2017) menyatakan bahwa umur perusahaan adalah kemampuan perusahaan dalam menjalankan bisnisnya sejak berdiri hingga sekarang. Perusahaan dengan umur yang lama juga memiliki pengendalian internal yang baik, dan juga mampu dalam mengumpulkan informasi yang dibutuhkan seorang auditor dalam melakukan pekerjaan auditnya (Agam, 2019). Menurut hasil penelitian Ryzkillah (2018) menyatakan bahwa umur perusahaan berpengaruh signifikan terhadap audit report lag yang mengindikasikan bahwa semakin lama atau semakin tua umur perusahaan maka mempunyai pengalaman yang lebih baik dibandingkan dengan perusahaan yang belum lama. Sedangkan Widiastuti \& Kartika (2018) menunjukkan bahwa umur perusahaan tidak berpengaruh terhadap audit report lag.

$\mathrm{H}_{2}$ : Umur perusahaan berpengaruh signifikan terhadap audit report lag

\section{Profitabilitas terhadap Audit Report Lag}

Menurut Harahap (2007 : 304), rasio profitabilitas merupakan kemampuan perusahaan dalam memperoleh keuntungan atau laba selama periode tertentu. Profitabilitas adalah hasil atau laba bersih dari berbagai kebijakan dan keputusan yang diambil oleh manajemen perusahaan, serta dapat memberi jawaban akhir tentang efektifitas pengelolaan perusahaan (Artaningrum, et.al., 2017). Dengan demikian dapat dikatakan bahwa profit merupakan berita baik bagi perusahaan. Perusahaan tidak akan menunda penyampaian informasi yang berisi berita baik. Perusahaan yang memiliki tingkat profitabilitas yang lebih tinggi membutuhkan waktu dalam pengauditan laporan keuangan lebih cepat dikarenakan keharusan untuk menyampaikan kabar baik secepatnya kepada publik. Menurut hasil penelitian Natalia, et.al., (2021) menyatakan bahwa profitabilitas berpengaruh signifikan terhadap audit report lag. Dimana tinggi rendahnya profitabilitas akan mempengaruhi penyampaian informasi terhadap laporan keuangan karena jika profitabilitas yang tinggi dapat mempercepat proses penyampaian yang merupakan berita yang baik dan dapat diinformasikan kepada investor atau masyarakat dan mendapat citra yang baik begitupun sama halnya jika profitabilitas perusahaan rendah maka perusahaan akan menunda publikasi informasi tersebut. Sedangkan menurut Sunarsih, et.al., (2021) menyatakan bahwa profitabilitas tidak berpengaruh signifikan terhadap audit report lag.

$\mathrm{H}_{3}$ : Profitabilitas berpengaruh signifikan terhadap audit report lag

\section{Solvabilitas terhadap Audit Report Lag}

Menurut Carslaw dan Kaplan (1991) menyatakan bahwa presentase dari hutang terhadap total aset mengindikasikan adanya kondisi keuangan dari sebuah perusahaan. Menurut Hanafi dan Halim (2007:81) solvabilitas merupakan kemampuan perusahaan dalam memenuhi kewajiban jangka panjang. Presentase yang tinggi dari hutang terhadap total aset akan membawa pengaruh solvabilitas yang terkait dengan masalah kelangsungan hidup sebuah perusahaan, sehingga perlu adanya kecermatan yang lebih dalam melakukan pengauditan. Semakin tingginya jumlah hutang yang dimiliki oleh perusahaan maka akan menyebabkan proses audit report lag yang relatif lebih panjang. Menurut penelitian yang dilakukan oleh Natalia, et.al., (2021) menunjukkan bahwa solvabilitas berpengaruh signifikan terhadap audit report lag. Sedangkan menurut Tannuka (2018) menyatakan bahwa solvabilitas tidak berpengaruh signifikan terhadap audit report lag.

$\mathrm{H}_{4}$ : Solvabilitas berpengaruh signifikan terhadap audit report lag

\section{Likuiditas terhadap Audit Report Lag}

Menurut Harahap (2007: 301), likuiditas adalah kemampuan perusahaan untuk memenuhi kewajiban jangka pendek. Menurut Sartika (2017) likuiditas adalah kemampuan perusahaan untuk memenuhi semua kewajiban-kewajiban jangka pendek. Perusahaan yang tidak likuid adalah perusahaan yang total utangnya lebih besar dibandingkan dengan total asetnya. Menurut Tannuka (2018) Likuiditas menunjukkan kemampuan perusahaan untuk memenuhi kewajibannya. Tingginya jumlah hutang yang dimiliki oleh perusahaan akan menyebabkan proses audit report lag yang relatif lebih panjang. Menurut penelitian yang dilakukan oleh Tampubolon dan Siagian (2020) 
dan penelitian Artaningrum, et.al., (2017) menunjukkan bahwa likuiditas berpengaruh signifikan terhadap audit report lag. Sedangkan menurut Tannuka., (2018) menyatakan bahwa likuiditas tidak berpengaruh signifikan terhadap audit report lag.

$\mathrm{H}_{5}$ : Likuiditas berpengaruh signifikan terhadap audit report lag

\section{METODE}

Objek penelitian yang digunakan adalah perusahaan pariwisata yang terdaftar di Bursa Efek Indonesia periode 2016 sampai 2020. Pemilihan sampel menggunakan metode purposive sampling, yang di pilih berdasarkan kriteria perusahaan yang terdaftar di BEI periode 2016 sampai 2020 dan perusahaan yang menyampaikan laporan keuangan tahunan dan telah diaudit periode 2016 sampai 2020 secara berturut-turut. Jumlah sampel yang memenuhi kriteria adalah sebanyak 16 perusahaan, jumlah data yang digunakan adalah sebanyak 80 data penelitian. Data yang digunakan dalam penelitian ini adalah data sekunder yang berbentuk laporan keuangan dan laporan auditor independen yang diperoleh dari www.idx.co.id. Analisis data yang digunakan dalam penelitian ini adalah analisis regresi data panel.

\section{Pengukuran Variabel}

Variabel dependen yang digunakan pada penelitian ini adalah Audit Report Lag. Variabel independen dalam penelitian ini adalah ukuran perusahaan, umur perusahaan, profitabilitas, solvabilitas dan likuiditas. Metode pengukuran setiap variabel pada penelitian ini adalah sebagai berikut:

Tabel 2 Pengukuran Variabel

\begin{tabular}{|l|l|}
\hline \multicolumn{1}{|c|}{ Variabel } & \multicolumn{1}{c|}{ Pengukuran } \\
\hline Audit Report Lag & Tanggal laporan audit - tanggal laporan keuangan \\
\hline Ukuran Perusahaan $\left(\mathrm{X}_{1}\right)$ & LnAsset \\
\hline Ukuran Perusahaan $\left(\mathrm{X}_{2}\right)$ & $\begin{array}{l}\text { Umur perusahaan = tahun penelitian - tahun perusahaan } \\
\text { terdaftar di BEI }\end{array}$ \\
\hline Profitabilitas $\left(\mathrm{X}_{4}\right)$ & Net Income dibagi dengan total asset, Return On Asset $(\mathrm{ROA})$ \\
\hline Solvabilitas $\left(\mathrm{X}_{5}\right)$ & $\begin{array}{l}\text { Total hutang dibandingkan dengan total ekuitas, Debt to } \\
\text { Equity Ratio (DER) }\end{array}$ \\
\hline Likuiditas $\left(\mathrm{X}_{6}\right)$ & $\begin{array}{l}\text { Aset lancar dibagi dengan kewajiban lancar ,Current Ratio } \\
(\mathrm{CR})\end{array}$ \\
\hline
\end{tabular}

HASIL

Berdasarkan data penelitian yang ada maka diperoleh hasil statistika deskriptif sebagai berikut:

Tabel 3 Hasil Uji Statistika Deskriptif

\begin{tabular}{ccccccc}
\hline & ARL & SIZE & UMUR & ROA & DER & CR \\
\hline Mean & 98.64 & 28.15 & 19.31 & 0.01 & 0.90 & 1.66 \\
Median & 86.00 & 28.04 & 20.00 & 0.01 & 0.75 & 1.55 \\
Maximum & 330.00 & 31.01 & 36.00 & 0.26 & 3.05 & 6.87 \\
Minimum & 0.000 & 26.39 & 0.000 & -0.26 & 0.12 & 0.24 \\
Std. Dev. & 40.16 & 1.24 & 8.80 & 0.07 & 0.60 & 1.09 \\
Observations & 80 & 80 & 80 & 80 & 80 & 80 \\
\hline
\end{tabular}

Sumber : Hasil Output Eviews 9 (2021)

Rata-rata Audit Report Lag (Y) adalah 98,64 hari, nilai minimum 0,000 hari, nilai maksimum 330,00 hari dengan standar deviasi 40,16. Hasil ini menunjukkan bahwa hampir semua perusahaan pariwisata yang terdaftar di BEI tahun 2016-2020 telah menyampaikan laporan keuangannya secara tepat waktu. Rata-rata Ukuran Perusahaan $\left(\mathrm{X}_{1}\right)$ adalah 28,15, nilai minimum sebesar 26,39, nilai maksimum sebesar 31,01 dengan standar deviasi 1,24. Hal ini dapat disimpulkan bahwa perusahaan dalam sampel penelitian ini memiliki ukuran perusahaan yang cukup besar jika dinilai dari total 
aset perusahaan. Rata-rata Umur Perusahaan $\left(\mathrm{X}_{2}\right)$ adalah 19,31 tahun, nilai minimum 0,000 yang dimiliki oleh PT Graha Andrasenta Propertindo Tbk yang baru listing di BEI pada tahun 2016 dan nilai maksimum sebesar 36,00 tahun yang dimiliki oleh PT Jakarta Internasional Hotel \& Development Tbk yang telah listing di BEI pada tahun 1984, dengan standar deviasi 8,80. Berdasarkan hasil pengujian tersebut dapat disimpulkan perusahaan pariwisata yang menjadi sampel dalam penelitian ini mayoritas telah lama listing di BEI. Rata-rata Profitabilitas $\left(\mathrm{X}_{4}\right)$ adalah 0,01 , nilai minimum $-0,26$, nilai maksimum 0,26 , dengan standar deviasi 0,07 . Rata-rata Solvabilitas $\left(\mathrm{X}_{5}\right)$ adalah 3,05, nilai minimum 0,12 , nilai maksimum 3,05 dengan standar deviasi 0,60 . Rata-rata Likuiditas $\left(X_{6}\right)$ adalah 1,66 , nilai minimum 0,24 , nilai maksimum 6,87 dengan standar deviasi 1,09.

Tabel 4. Hasil Uji Multikolonieritas

\begin{tabular}{cccccc}
\hline & SIZE & UMUR & ROA & DER & CR \\
\hline SIZE & 1.000000 & -0.027212 & 0.233898 & -0.320642 & 0.270085 \\
UMUR & -0.027212 & 1.000000 & 0.000831 & -0.379520 & -0.064681 \\
ROA & 0.233898 & 0.000831 & 1.000000 & -0.369871 & 0.190680 \\
DER & -0.320642 & -0.379520 & -0.369871 & 1.000000 & -0.157466 \\
CR & 0.270085 & -0.064681 & 0.190680 & -0.157466 & 1.000000 \\
\hline
\end{tabular}

Sumber : Hasil Output Eviews 9 (2021)

Berdasarkan tabel 4 hasil uji multikolonieritas di atas dapat diketahui bahwa hasil perhitungan nilai korelasi antar variabel independen kurang dari 0,9 yang artinya bahwa korelasi antar variabel independen tidak terjadi multikolonieritas.

Tabel 5. Hasil Uji Heteroskesdastisitas

\begin{tabular}{cc}
\hline Variabel & Prob. \\
\hline C & 0.9995 \\
SIZE & 0.9498 \\
UMUR & 0.8970 \\
ROA & 0.1986 \\
DER & 0.5667 \\
CR & 0.4876 \\
\hline
\end{tabular}

Sumber : Hasil Output Eviews 9 (2021)

Berdasarkan tabel 5 hasil uji heteroskesdastisitas di atas menunjukkan bahwa nilai probabilitas seluruh variabel independen lebih dari 0,05. Maka dapat disimpulkan bahwa model regresi yang digunakan dalam penelitian ini bebas dari masalah heteroskedastisitas.

Redundant Fixed Effects Tests

Tabel 6. Hasil Uji Chow

\begin{tabular}{lrrr}
\hline Effects Test & \multicolumn{1}{c}{ Statistic } & d.f. & Prob. \\
\hline Cross-section F & 3.020914 & $(15,59)$ & 0.0012 \\
Cross-section Chi-square & 45.589228 & 15 & 0.0001 \\
\hline
\end{tabular}

Sumber : Hasil Output Eviews 9 (2021)

Berdasarkan tabel 6 hasil uji Chow di atas menunjukkan bahwa nilai probabilitas cross section adalah $0,0012<0,05$, maka model yang dipilih yaitu fixed effect model.

Tabel 7. Hasil Uji Hausman

Correlated Random Effects - Hausman Test

\begin{tabular}{lrrr}
\hline Test Summary & Chi-Sq. Statistic & Chi-Sq. d.f. & Prob. \\
\hline Cross-section random & 19.930420 & 5 & 0.0013
\end{tabular}

Sumber : Hasil Output Eviews 9 (2021) 
Owner: Riset \& Jurnal Akuntansi

e-ISSN : 2548-9224 | p-ISSN : 2548-7507

Volume 6 Nomor 1, Januari 2022

DOI : https://doi.org/10.33395/owner.v6i1.623

Berdasarkan tabel 7 hasil uji Hausman di atas menunjukkan bahwa nilai probabilitas cross section adalah $0,0013<0,05$ maka model regresi yang tepat digunakan dalam penelitian ini adalah fixed effect model

\section{Hasil Regresi Data Panel}

Tabel 8. Hasil Regresi Data Panel dengan Fixed Model Effect

\begin{tabular}{ccccc}
\hline Variable & Coefficient & Std. Error & t-Statistic & Prob. \\
\hline C & 36.51867 & 346.2204 & 0.105478 & 0.9164 \\
SIZE & -3.792193 & 12.76558 & -0.297064 & 0.7675 \\
UMUR & 8.591616 & 2.752763 & 3.121088 & 0.0028 \\
ROA & -252.7762 & 79.73987 & -3.170010 & 0.0024 \\
DER & 0.545016 & 13.48242 & 0.040424 & 0.9679 \\
CR & 2.888311 & 4.373738 & 0.660376 & 0.5116 \\
\hline
\end{tabular}

Sumber : Hasil Output Eviews 9 (2021)

Persamaan regresi data panel dapat dirumuskan sebagai berikut:

$\mathrm{Y}=36,519-3,792 \mathrm{X}_{1}+8,591 \mathrm{X}_{2}-252,776 \mathrm{X}_{3}+0,545 \mathrm{X}_{4}+2,888 \mathrm{X}_{5}+\varepsilon$

Keterangan:

$\mathrm{Y}=$ Audit Report Lag

$\mathrm{X}_{1} \quad=$ Ukuran Perusahaan

$\mathrm{X}_{2}=$ Umur Perusahaan

$\mathrm{X}_{3} \quad=$ Profitabilitas

$\mathrm{X}_{4} \quad=$ Solvabilitas

$\mathrm{X}_{5} \quad=$ Likuiditas

$\varepsilon \quad=$ error

\section{Uji Hipotesis}

Tabel 9 Hasil Uji Koefisien Determinasi

\begin{tabular}{|c|c|}
\hline Variabel Dependen & Adjusted R-squared \\
\hline Audit Report Lag & 0.479559 \\
\hline
\end{tabular}

Sumber : Output Eviews 9 (2021)

Berdasarkan tabel 9 hasil uji koefisien determinasi $\left(\mathrm{R}^{2}\right)$ di atas, menunjukkan hasil nilai Adjusted $R$ Square adalah 0,479. Hal ini menunjukkan bahwa 47,9\% variabel dependen Audit Report Lag dapat dijelaskan oleh variabel independen yaitu Ukuran Perusahaan, Umur Perusahaan, Profitabilitas, Solvabilitas dan Likuiditas. Sedangkan sisanya sebesar 52,1\% dijelaskan oleh variabel - variabel lain di luar penelitian ini.

Tabel 4.10 Hasil Uji F

\begin{tabular}{lrlr}
\hline R-squared & 0.611316 & Mean dependent var & 98.63750 \\
Adjusted R-squared & 0.479559 & S.D. dependent var & 40.15831 \\
S.E. of regression & 28.97084 & Akaike info criterion & 9.790968 \\
Sum squared resid & 49519.28 Schwarz criterion & 10.41625 \\
Log likelihood & -370.6387 & Hannan-Quinn criter. & 10.04166 \\
F-statistic & 4.639718 Durbin-Watson stat & 2.592490 \\
Prob(F-statistic) & 0.000002 & \\
\hline
\end{tabular}

Sumber: Hasil Output Eviews 9 (2021)

Berdasarkan tabel 11 hasil uji f di atas nilai probabilitas $F$-statistic sebesar 0,000002 < 0,05. Hal ini berarti menunjukkan Ukuran Perusahaan, Umur Perusahaan, Profitabilitas, Solvabilitas dan Likuiditas secara bersama - sama (simultan) berpengaruh terhadap Audit Report Lag.

Tabel 11 Hasil Uji T 
Owner: Riset \& Jurnal Akuntansi

e-ISSN : 2548-9224 | p-ISSN : 2548-7507

Volume 6 Nomor 1, Januari 2022

DOI : https://doi.org/10.33395/owner.v6i1.623

\begin{tabular}{ccccc}
\hline Variable & Coefficient & Std. Error & t-Statistic & Prob. \\
\hline C & 36.51867 & 346.2204 & 0.105478 & 0.9164 \\
SIZE & -3.792193 & 12.76558 & -0.297064 & 0.7675 \\
UMUR & 8.591616 & 2.752763 & 3.121088 & 0.0028 \\
ROA & -252.7762 & 79.73987 & -3.170010 & 0.0024 \\
DER & 0.545016 & 13.48242 & 0.040424 & 0.9679 \\
CR & 2.888311 & 4.373738 & 0.660376 & 0.5116 \\
\hline
\end{tabular}

Sumber: Hasil Output Eviews 9 (2021)

Berdasarkan tabel 11 hasil uji t menunjukkan bahwa variabel umur perusahaan berpengaruh signifikan positif terhadap audit report lag, serta profitabilitas berpengaruh signifikan negatif terhadap audit report lag. Sedangkan ukuran perusahaan, solvabilitas dan likuiditas tidak memiliki pengaruh secara signifikan terhadap audit report lag.

\section{Ukuran perusahaan berpengaruh signifikan terhadap audit report lag}

Nilai signifikansi variabel ukuran perusahaan adalah sebesar 0,7675. Hal ini menunjukkan $\mathrm{H}_{1}$ ditolak yang berarti bahwa ukuran perusahaan tidak berpengaruh signifikan terhadap Audit Report Lag. Hal ini disebabkan karena total aset yang dimiliki oleh perusahaan lebih maka dapat menyebabkan lamanya penyelesaian audit terhadap laporan keuangan. Menurut Tannuka (2018) berpendapat bahwa perusahaan yang telah terdaftar di BEI akan diawasi oleh investor, regulator, dan berbagai pihak yang memiliki kepentingan atas laporan keuangan perusahaan. Oleh karena itu, perusahaan dituntut untuk dapat menyelesaikan proses audit laporan keuangan dan melakukan penyampaian laporan keuangan secara tepat waktu. Hasil penelitian ini konsisten dengan penelitian yang dilakukan oleh Natalia, et.al., (2021); Rahayu, et.al., (2021); Agam (2019); Tannuka (2018); dan Widhiasari dan Budhiarta (2017).

\section{Umur perusahaan berpengaruh signifikan terhadap audit report lag}

Nilai signifikansi variabel umur perusahaan adalah sebesar 0,0028. Hal ini menunjukkan $\mathrm{H}_{2}$ diterima yang berarti bahwa umur perusahaan berpengaruh signifikan terhadap Audit Report Lag. Hal ini disebabkan karena perusahaan yang telah lama berdiri pasti sudah cukup mengetahui dan telah menghadapi masalah - masalah pengalaman dalam menjalankan bisnisnya, sehingga perusahaan yang lama berdiri mampu menyajikan laporan keuangan dengan baik. Perusahaan dengan umur yang lama juga memiliki pengendalian internal yang baik, dan juga mampu dalam mengumpulkan informasi yang dibutuhkan seorang auditor dalam melakukan pekerjaan auditnya. Tentunya akan mempercepat proses audit yang nantinya akan berpengaruh terhadap audit report lag. Hasil penelitian ini konsisten dengan penelitian Ryzkillah (2018) serta penelitian Widhiasari dan Budhiarta (2017).

\section{Profitabilitas berpengaruh signifikan terhadap audit report lag}

Nilai signifikansi variabel profitabilitas adalah sebesar 0,0024 . Hal ini menunjukkan $\mathrm{H}_{3}$ diterima yang berarti bahwa profitabilitas berpengaruh signifikan terhadap Audit Report Lag. Hal ini disebabkan karena perusahaan tidak akan menunda penyampaian informasi yang berisi berita baik. Oleh karena itu, perusahaan yang mampu menghasilkan laba akan cenderung mengalami audit report lag yang lebih pendek, sehingga good news tersebut dapat segera disampaikan kepada investor dan pihak - pihak yang berkepentingan lainnya. Hal ini di karenakan tingkat keuntungan dipakai sebagai salah satu cara untuk menilai keberhasilan efektivitas perusahaan, yang berkaitan dengan hasil kerja dari berbagai kebijakan dan keputusan yang telah dilaksanakan oleh perusahaan dalam periode berjalan. Perusahaan yang mendapatkan laba akan memiliki insentif untuk menginformasikan ke publik kinerja unggul mereka degan mengeluarkan laporan tahunan secara tepat waktu. Sedangkan perusahaan yang mengalami kerugian maka penerbitan laporan keuangan akan ditunda karena hal tersebut merupakan bad news. Hasil penelitian ini konsisten dengan penelitian Natalia, et.al,. (2021); Agam (2018); Widiastuti \& Kartika (2018); Tannuka (2018); seta penelitian Dura (2017). 


\section{Solvabilitas berpengaruh signifikan terhadap audit report lag}

Nilai signifikansi variabel solvabilitas adalah sebesar 0,9679. Hal ini menunjukkan $\mathrm{H}_{4}$ ditolak yang berarti bahwa solvabilitas tidak berpengaruh signifikan terhadap Audit Report Lag. Perusahaan yang mendapatkan solvabilitas yang tinggi maupun rendah tentu saja mendapatkan prosedur audit yang sama dan telah sesuai dengan standarnya (Alip, 2021). Oleh karena itu, apabila pihak manajemen perusahaan dapat menjelaskan penyebab tingginya hutang perusahaan terhadap total asset yang dimiliki oleh perusahaan, sehingga tinggi maupun rendahnya hutang yang dimiliki oleh perusahaan bukan salah satu faktor yang mempengaruhi audit report lag. Hasil penelitian ini konsisten dengan penelitian Prabowo (2019); Tannuka (2018).

\section{Likuiditas berpengaruh signifikan terhadap audit report lag}

Nilai signifikansi variabel lukuiditas adalah sebesar 0,5116. Hal ini menunjukkan $\mathrm{H}_{5}$ ditolak yang berarti bahwa likuiditas tidak berpengaruh signifikan terhadap Audit Report Lag. Perusahaan menginginkan penyampaian laporan keuangan secara tepat waktu tanpa mempertimbangkan tingkat likuiditas yang tinggi atau rendah, hal ini bertujuan untuk memberikan informasi kepada pihak ketiga (kreditor) mengenai kemampuan sebuah perusahaan dalam memenuhi kewajibannya (Tannuka, 2018). Hasil penelitian ini konsisten dengan penelitian yang dilakukan oleh Tannuka (2018).

\section{KESIMPULAN}

Berdasarkan hasil penelitian yang telah dilakukan maka dapat ditarik kesimpulan bahwa umur perusahaan dan profitabilitas berpengaruh secara signifikan terhadap Audit Report Lag. Ukuran perusahaan, Solvabilitas dan Likuiditas tidak berpengaruh secara signifikan terhadap Audit Report Lag. Keterbatasan penelitian ini adalah pemilihan sampel yang hanya terbatas pada perusahaan pariwisata yang terdaftar di Bursa Efek Indonesia, periode penelitian hanya terbatas selama tahun 2016-2020 dan hanya menggunakan lima variabel independen. Oleh karena itu, dengan adanya keterbatasan penelitian ini maka peneliti menyarankan untuk penelitian berikutnya, penelitian ini dapat dikembangkan dengan menggunakan faktor-faktor Audit Report Lag lainnya seperti rasio opini audit, reputasi KAP, ukuran KAP, pergantian auditor, audit tenure, laba rugi, kualitas audit, komite audit, kepemilikan publik, pergantian manajemen, reputasi auditor dan lain sebagainya sebagai predikator terhadap audit report lag. Bagi peneliti selanjutnya sebaiknya menambah variabel, memperpanjang periode penelitian serta menambah jumlah perusahaan yang terdaftar di Bursa Efek Indonesia (BEI) lainnya dan tidak hanya perusahaan sektor pariwisata saja. Karena semakin banyak sampel dan populasi yang diambil akan meningkatkan kualitas penelitian beserta hasilnya.

\section{REFERENSI}

Abdul, Halim. (2000). Auditing. Yogyakarta: UPP AMP YKPN.

Agam, Dino, R. (2019). Pengaruh Profitabilitas, Solvabilitas, Opini Audit, Umur Perusahaan, dan Ukuran Perusahaan terhadap Audit Report Lag (Studi Empiris pada Perusahaan Manufaktur Sektor Aneka Industri yang Terdaftar dalam Bursa Efek Indonesia Tahun 20162018). Fakultas Ekonomi Universitas Islam Indonesia. Yogyakarta. https://dspace.uii.ac.id/123456789/18353.

Al Fajar, M.A.(2021). Pengaruh Profitabilitas, Solvabilitas, Laba Rugi, Opini Audit, dan Umur Perusahaan terhadap Audit Report Lag pada Perusahaan Pertambangan yang Terdaftar di Bursa Efek Indonesia Tahun 2016-2020. Program Studi Akuntansi Fakultas Ekonomika dan Bisnis. Universitas Pancasakti Tegal. Tegal. http://repository.upstegal.ac.id/id/eprint/4053/.

Aristika, Manda Novy et, al. (2016). Pengaruh Opini Audit, Ukuran Perusahaan, Umur Perusahaan, dan Laba Rugi terhadap Audit Delay. ISSN 2460-0784 Syariah Paper Accounting FEB $U M S$.

Artaningrum, R.G, Budhiarta, I.K, \& Wirakusuma, M.G. (2017). Pengaruh Profitabilitas, Solvabilitas, Likuiditas, Ukuran Perusahaan dan Pergantian Manajemen pada Audit Report 
Owner: Riset \& Jurnal Akuntansi

e-ISSN : 2548-9224 |p-ISSN : 2548-7507

Volume 6 Nomor 1, Januari 2022

DOI : https://doi.org/10.33395/owner.v6i1.623

Lag Perusahaan Perbankan. E-Jurnal Ekonomi dan Bisnis Universitas Udayana, 6(3), 1079-

1108. https://ojs.unud.ac.id/index.php/EEB/article/view/24231.

bapepam-LK. (2011). Peraturan Bapepam-LK No.X.K.2, Lampiran Keputusan Ketua Bapepam dan LK Nomor. KEP-346/BL/2001 menyangkut keharusan dalam menyajikan financial statement secara berkala.

Carslaw, Charler, A.P.N \& Steven E. Kaplan. (1991). An Examination of Audit Delay: Futher Evidannce From New Zeland. Accounting and Business Research, 22(85), 21-23.

Desiana, \& Wildan, D.D. (2020). Pengaruh Ukuran Perusahaan dan Profitabilitas terhadap Audit Report Lag. Jurnal Akuntansi, 15(1), 36-43.

Dura, Justita. (2017). Pengaruh Profitabilitas, Likuiditas, Solvabilitas, dan Ukuran Perusahaan terhadap Audit Report Lag pada Perusahaan yang Terdaftar di Bursa Efek Indonesia (Studi $\begin{array}{lllll}\text { Kasus Pada Sektor } \quad \text { Manufaktur). } & \text { JIBEKA, }\end{array}$ https://doi.org/0.32812/jibeka.v11i1.34.

Harahap, Sofyan, S. (2007). Analisis Kritis atas Laporan Keuangan. Edisi Kesatu: Jakarta. PT Raja Grafindo Persada.

Ikatan Akuntansi Indonesia (IAI). (2009). Pernyataan Standar Akuntansi Keuangan (PSAK). Jakarta : Salemba Empat.

Jensen, M. C and Meckling, W.H. (1976). Theory of the Firm : Managerial Behavior, Agency Costs and Ownership Structure. Journal of Financial Economics, 3(4), 305-360

Knechel W.R \& J.L. Payne. (2001). Additional Evidence An Audit Report Lag. Auditing: Ajournal of Practice An Theory. (Vol. 20 No. 1). March: 137-145.

Natalia, C., Destiny., \& Putri, A. (2021). Pengaruh Ukuran Perusahaan, Solvabilitas, Profitabilitas, Umur Perusahaan terhadap Audit Delay pada Sektor Pariwisata di BEI. Jurnal Ilmiah MEA (Manajemen, Ekonomi, dan Akuntansi), 5(3). https://doi.org/10.31955/mea.vol5.iss3.pp933947.

Pertiwi, B.D. (2021). Faktor-faktor yang Mempengaruhi Audit Report Lag pada Perusahaan Manufaktur (Studi Empiris pada Perusahaan Manufaktur yang Terdaftar di Bursa Efek Indonesia Tahun 2017-2019). Program Studi Akuntansi Fakultas Ekonomika dan Bisnis, Universitas Muhammadiyah Surakarta. Surakarta. https://eprints.ums.ac.id/id/eprint/94763.

Rahayu, P., Khikmah., S.N., Dewi, V.S. (2021). Pengaruh Ukuran Perusahaan, Profitabilitas, Solvabilitas, Ukuran KAP dan Financial Distress terhadap Audit Report Lag. Business and Economics Conference in Utilization of Modern Technology. pp. 467-486.

Rizkyllah, Permana. (2018). Pengaruh Opini Audit, Komite Audit, dan Umur Perusahaan terhadap Audit Report Lag pada Perusahaan yang Terdaftar di Bursa Efek Indonesia Tahun 20112016. Sekolah Tinggi Ilmu Ekonomi Perbanas. Surabaya. http://eprints.perbanas.ac.id/id/eprint/3478.

Siregar, I.A.U., \& Sujiman, L.S. (2021). Pengaruh Profitabilitas, Solvabilitas dan Ukuran Perusahaan terhadap Audit Report Lag pada Perusahaan Manufaktur Sub Sektor Makanan dan Minuman yang Terdaftar di BEI Periode 2018-2020.

Sunarsih, N.M., Munidewi, I.A.B., Masdiasari, N.K.M. (2021). Pengaruh Ukuran Perusahaan, Profitabilitas, Solvabilitas, Kualitas Audit, Opini Audit, Komite Audit terhadap Audit Report Lag. Jurnal KRISNA: Kumpulan Riset Akuntansi, 13(1), 1-13. https://doi.org/10.22225/kr.13.1.2021.1-13.

Tannuka, Sugi. (2018). Pengaruh Ukuran Perusahaan, Profitabilitas, Solvabilitas, Likuiditas dan Ukuran KAP terhadap Audit Report Lag(Studi Empiris Pada Perusahaan Properti, Real Estate, dan Konstruksi Bangunan yang Terdaftar di Bursa Efek Indonesia Periode 20112015). Jurnal Muara Ilmu Ekonomi dan Bisnis, 2(2), 354-368. https://doi.org/10.24912/jmieb.v12i2.1312.

Weygandt, Kimmel, \& Kieso, (2013). Financial Accounting: IFRS Edition. John Wiley \& Sons, Inc.

Widiastuti, I., \& Kartika, Andi. (2018). Ukuran Perusahaan, Profitabilitas, Umur Perusahaan, Solvabilitas, dan Ukuran KAP terhadap Audit Report Lag. Dinamika Akuntansi, Keuangan dan Perbankan, 7(1), 20-34.

www.idx.com 